\title{
Comparative Effect of City Finished Compost and NPK Fertilizer on Growth and Availability of Phosphorus to Radish (Raphanus sativus L.)
}

\author{
Ashoka Sarker, Md. Abul Kashem*, Khan Towhid Osman
}

Department of Soil Science, University of Chittagong, Chittagong, Bangladesh.

Email: *kashem00@yahoo.com

Received February 23 ${ }^{\text {rd }}, 2012$; revised March 20 $0^{\text {th }}$, 2012; accepted April $7^{\text {th }}, 2012$

\begin{abstract}
A pot experiment was carried out to investigate the comparative effect of city finished compost and NPK fertilizer on the growth and availability of phosphorus to radish (Raphanus sativus L.). An air dried sandy loam soil was mixed with five rates of city finished compost (CFC) equivalent to $0,5,10,20,40$ ton $\mathrm{ha}^{-1}$ and three rates of NPK fertilizer equivalent to $50 \%\left(\mathrm{~N}-\mathrm{P}-\mathrm{K}=69-16-35 \mathrm{~kg} \cdot \mathrm{ha}^{-1}\right), 100 \%\left(\mathrm{~N}-\mathrm{P}-\mathrm{K}=137-32-70 \mathrm{~kg} \cdot \mathrm{ha}^{-1} \mathrm{~K}\right)$ and $150 \%(\mathrm{~N}-\mathrm{P}-\mathrm{K}=206-48-105$ $\left.\mathrm{kg} \cdot \mathrm{ha}^{-1}\right)$. Four plants were harvested at 45 days of growth and remaining one plant was harvested at 90 days of growth and separated into leaves and bulbs. After harvest, soil samples were collected from each pot to measure soil $\mathrm{pH}$ and available P extracted by Olsen, Mehlich-3, Kelowna and Bray \& Kurtz-1 extractants. The growth parameters (length of leaves and bulbs, fresh and dry weight of leaves and bulbs), relative dry matter yield, plant P concentrations, P uptake by radish, soil $\mathrm{pH}$, and available $\mathrm{P}$ increased by the rates of CFC and NPK fertilizer treatments. Among the treatments, growth performance of radish was better with the highest rate of $40 \mathrm{t} \cdot \mathrm{ha}^{-1} \mathrm{CFC}$ treatments. The results obtained from the 5 and $10 \mathrm{t} \cdot \mathrm{ha}^{-1} \mathrm{CFC}$ treatment were comparable with the results of $50 \%$ and $100 \%$ NPK fertilizer treatments respectively. Similar effects of amendments were obtained in the case of plant $\mathrm{P}$ concentration, uptake of $\mathrm{P}$ by plant, soil $\mathrm{pH}$ and available soil $\mathrm{P}$ concentration. Available $\mathrm{P}$ and soil $\mathrm{pH}$ showed very strong and positive correlation $(P<0.001)$ with dry matter yield, $\mathrm{P}$ uptake by plant. The $\mathrm{P}$ extracted by various extractants also showed strong positive correlation $(\mathrm{r}=$ 0.973 to $0.994 ; P<0.001$ ) each other indicating the suitability of any of the extractants to predict available P. Results of the present study indicated that $10 \mathrm{t} \cdot \mathrm{ha}^{-1}$ city finished compost could be used instead of $100 \%$ to obtain similar yield and to improve soil conditions.
\end{abstract}

Keywords: Compost; Soil; Extraction Methods; Growth; Phosphorus; Radish

\section{Introduction}

With increasing demand of agricultural production and as the peak in global production will occur in the next decades, phosphorus is receiving more attention as a nonrenewable resource [1,2]. Applications of chemical P fertilizers to agricultural land have improved soil P fertility and crop production, but caused environmental damage in the past decades. In addition, the use of inorganic fertilizers has not been helpful under intensive agriculture because it is often associated with reduced yield, nutrient imbalance, leaching and pollution of groundwater $[3,4]$. Organic manure can serve as alternative practice to mineral fertilizers $[5,6]$ for improving soil structure $[7,8]$ and microbial biomass [9]. Improved yields of various crops have been reported by addition of organic manures [1012]. Plants grown with organic manures accumulate

\footnotetext{
*Corresponding author.
}

more P than without organic amendments [13]. Organic amendments contain considerable amounts of organic $P$ which are mineralized and provide available $\mathrm{P}$ to plant. On decomposition, organic matters liberate $\mathrm{P}$ in soil and accumulate organic acids, which interact with soil complexes to affect the availability through different mechanisms [14].

The application of organic waste or compost on soils used for crop production is of great importance due to the nutritional input and low cost [15]. Additionally, composting is one of the best solutions to reduce the huge piles of organic wastes and convert it in to a value added product. It is one of the major recycling processes by which nutrients present in organic materials are returned back to the soil in plant available form [16]. Also, pathogens are eliminated during composting, and so this process produces an adequate agricultural product $[17,18]$. City finished compost (CFC), an important organic source 
of $\mathrm{P}$ is effective in increasing the availability of $\mathrm{P}$ as compost additions improve the fertility and the physicochemical properties of soils $[18,19]$. The availability of city wastes $\mathrm{P}$ to crops and its impact on soil P may differ from that of inorganic P fertilizer [21-24]. Some studies have suggested that $\mathrm{P}$ in organic amendments may be equally or more available than fertilizer P [22]. These findings emphasize the need for studying the use of city finished compost (CFC) and NPK fertilizer to compare their effects on the growth and availability of nutrient to plants.

Radish (Raphanus sativus L.) one of the important and popular vegetable crops in Bangladesh was used as a test plant in this study. The main objective of this study was to investigate the effect of city finished compost and NPK fertilizer on growth and availability of phosphorus to radish.

\section{Materials and Methods}

\subsection{Plant Growth Experiment}

A pot experiment was carried out in the crop field of the Department of Soil Science, University of Chittagong, Bangladesh, using a sandy loam surface soil $(0-15 \mathrm{~cm})$. Soil sample was air dried and passed through 4-mm sieve for using it in the pots. For laboratory analysis, a sub sample was air dried and passed through a 2-mm sieve and stored. Soil pH was of 5.07 (1:2.5 soil to water ratio), organic carbon [25] was $0.93 \%$ and CEC (extraction with $1 \mathrm{M} \mathrm{NH} 4 \mathrm{OAc}$ ] [26] was of $4.01 \mathrm{cmol} \cdot \mathrm{kg}^{-1}$. The soil contained $73 \%$ sand, $13 \%$ silt and $14 \%$ clay measured by hydrometer method [27]. City finished compost (CFC) was collected from the composting plant of Chittagong City Corporation, Halishahar, Chittagong and ground, sieved and analyzed for chemical properties. The $\mathrm{pH}$ of CFC was 7.13. Five rates of CFC equivalent to 0 (control), 5, 10, 20, $40 \mathrm{t} \cdot \mathrm{ha}^{-1}$ and three NPK fertilizer rates equivalent to $50 \%\left(\mathrm{~N}-\mathrm{P}-\mathrm{K}=69-16-35 \mathrm{~kg} \cdot \mathrm{ha}^{-1}\right), 100 \%$ $\left(\mathrm{N}-\mathrm{P}-\mathrm{K}=137-32 \mathrm{P}-70 \mathrm{~kg} \cdot \mathrm{ha}^{-1}\right)$, and 150\% (N-P-K $=206$ $-48-105 \mathrm{~kg} \cdot \mathrm{ha}^{-1}$ ) were applied separately in each pot containing four (4) $\mathrm{kg}$ soil. The pots were arranged in a completely randomized design (CRD) with three replications. Eight seeds of radish were sown to each pot and water was applied up to the field capacity. After emergence, 5 healthy seedlings were kept in each pot. The plants were harvested two times from the same pot. Out of 5 plants, 4 plants were harvested at 45 days of growth and another 1 plant was harvested at 90 days of growth (Figure 1). After each harvest, the plants were separated into leaves and bulbs. The length of the leaves and bulbs with fresh weight were recorded. The leaves and bulbs were air dried for several days and oven dried at $65^{\circ} \mathrm{C}$ for 72 hours and dry mass was recorded. Soil samples were
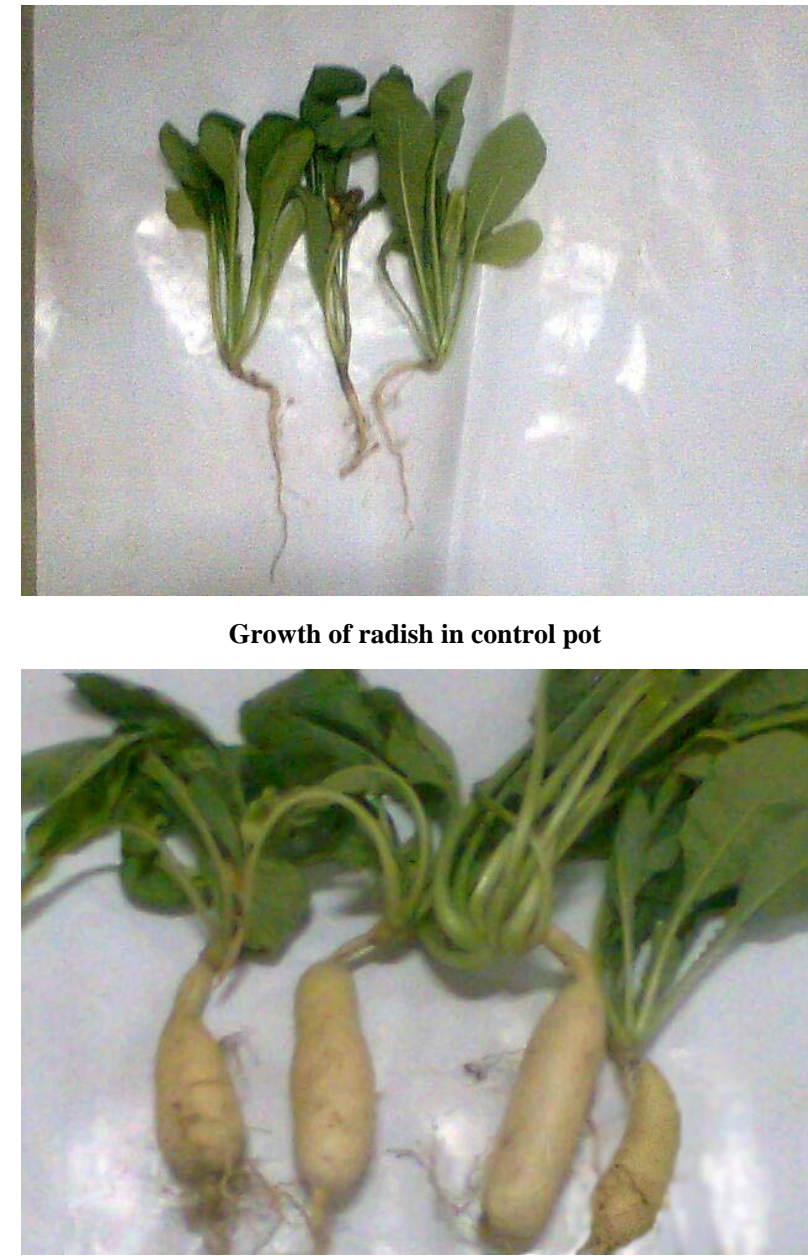

Growth of radish in CFC treated pots

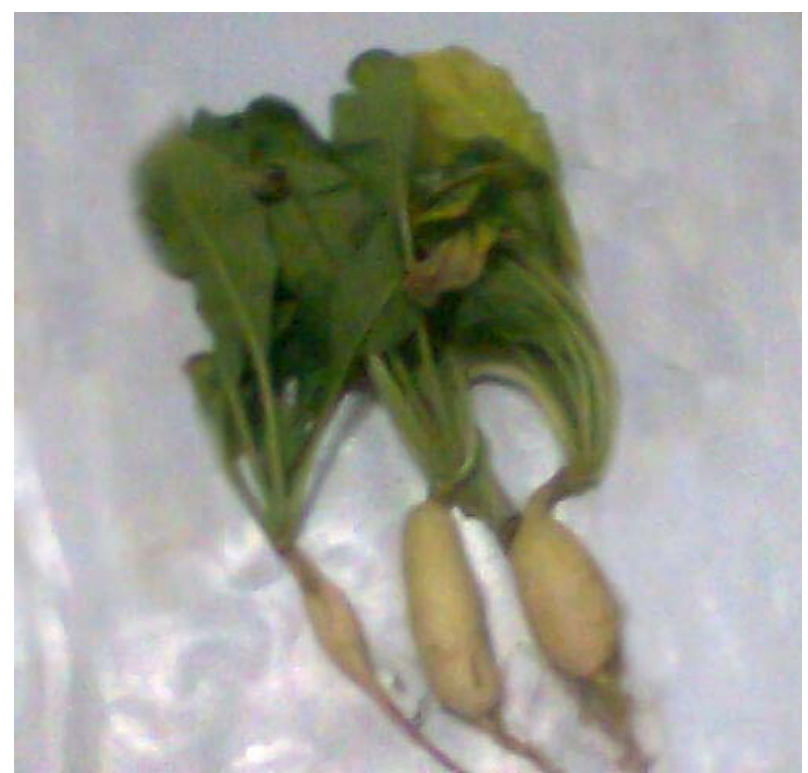

Growth of radish in NPK treated pots

Figure 1. Effect of CFC and NPK fertilizer on growth of radish at 90 days of growth. 
collected from each pot after harvest to measure soil $\mathrm{pH}$ and extractable P by four extraction methods such as Olsen [28], Mehlich-3 [29], Kelowna [30] and Bray and Kurtz-1 [31].

Total $\mathrm{P}$ in the soil, CFC and in the plant tissues were determined colorimetrically by ascorbic acid blue color method [32] after digestion with $\mathrm{H}_{2} \mathrm{O}_{2}-\mathrm{H}_{2} \mathrm{SO}_{4}$ [33] and the absorbance was measured by spectrophotometer at wave length of $882 \mathrm{~nm}$. Total phosphorus concentration in the experimental soil and CFC were $100 \mathrm{mg} \cdot \mathrm{kg}^{-1}$ and $7100 \mathrm{mg} \cdot \mathrm{kg}^{-1}$, respectively. Extractable P of the soil was determined by the same procedure as mentioned above after extraction with different extractants. The available phosphorous of the soil sample extracted by $0.5 \mathrm{M} \mathrm{Na}$ $\mathrm{HCO}_{3}$ (Olsen), Mehlich-3, Kelowna and Bray and Kurtz1 method were $1.37,4.95,4.76$ and $4.93 \mathrm{mg} \cdot \mathrm{kg}^{-1}$ respectively. The $\mathrm{P}$ uptake of the plants was calculated by multiplying the $\mathrm{P}$ concentration in the tissue and the dry matter (DM) yield.

\subsection{Statistical Analysis}

Microsoft Excel and MINITAB program [34] were used for analysis of variance and correlation.

\section{Results}

\subsection{Plant Growth}

City finished compost and NPK fertilizer application substantially influenced the plant growth. The height of leaves and bulbs of radish both at 45 and 90 days of growth increased significantly $(P<0.001)$ with the rates of CFC and NPK fertilizer application. At both growth periods, the maximum height was observed at the highest rate of CFC $\left(40 \mathrm{t} \cdot \mathrm{ha}^{-1}\right)$ and NPK (150\%) treatments. With the duration of growth, these two parameters increased but the treatment effects were found similar at both 45 and 90 days of growth (Table 1).

The fresh and dry weights of leaves and bulbs also increased with the rates of amendments and the duration of growth. Total fresh weight of radish (leaves plus bulb) increased 6 and 4 folds by the application of $40 \mathrm{t} \cdot \mathrm{ha}^{-1}$ CFC and 150\% NPK treatments, respectively over the control, the corresponding values of total dry weight increased were of 8 and 5 folds of the control at 45 days of

Table 1. Effect of CFC and NPK fertilizer on growth and yield of radish at 45 and 90 days of growth.

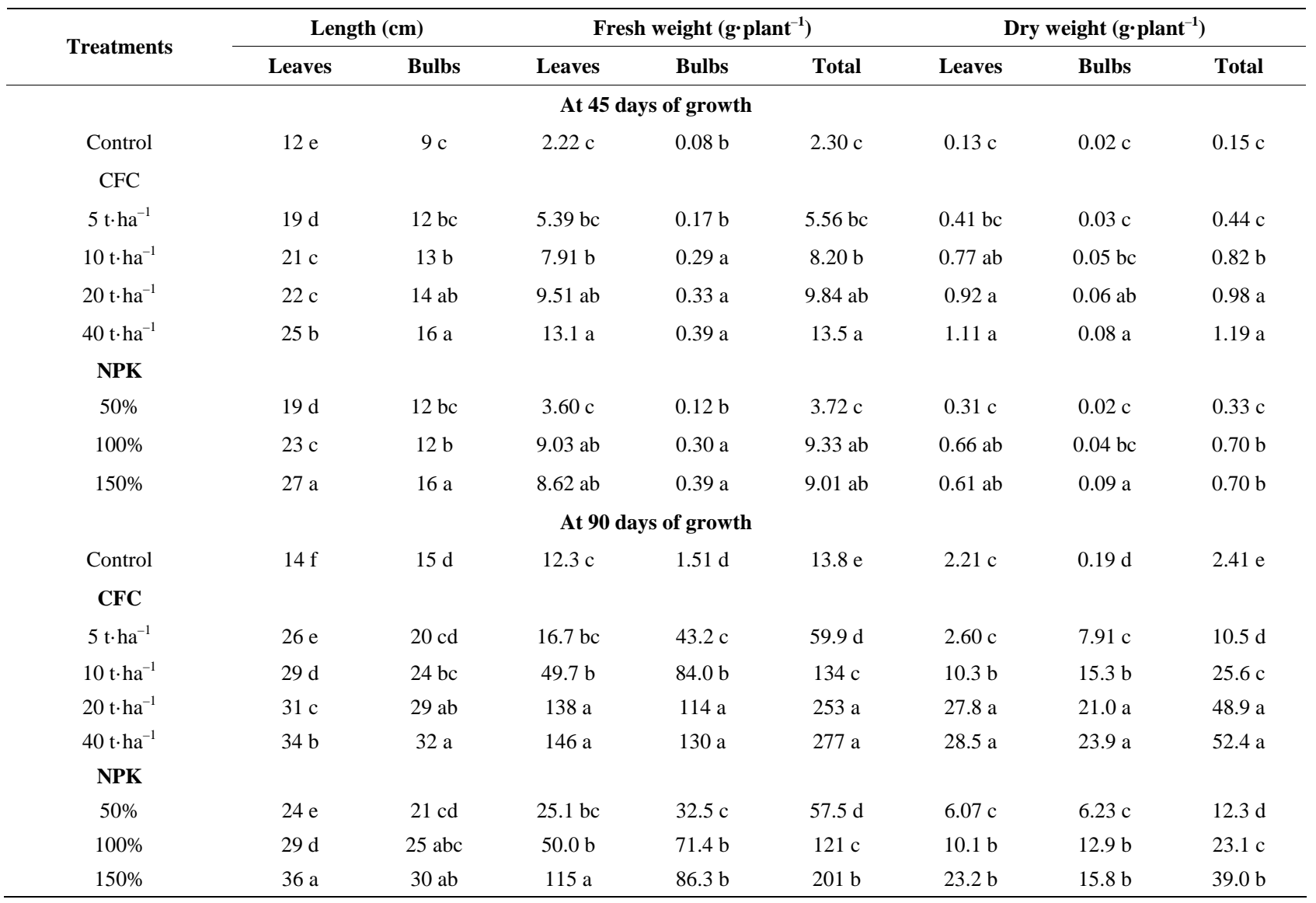

Means followed by the same letter(s) in column(s) are not significantly different at $P<0.05$. 
growth (Table 1). At 90 days of growth, the magnitude of total dry weight increase was of 21 folds by the 40 $\mathrm{t} \cdot \mathrm{ha}^{-1}$ CFC treatment and of 16 folds by the $150 \%$ NPK treatments over the control indicating better growth performance with the CFC than those with NPK fertilizer treatments.

\subsection{Phosphorus Concentration in Plant Parts and Phosphorus Uptake by Plant}

Phosphorus concentration in leaves and bulbs and uptake of $\mathrm{P}$ by radish at two stages of growth varied significantly $(\mathrm{P}<0.001)$ with CFC and NPK fertilizer amendments. At 45 days of growth, $\mathrm{P}$ concentration in leaves ranged from $1788 \mathrm{mg} \cdot \mathrm{kg}^{-1}$ in control to $5052 \mathrm{mg} \cdot \mathrm{kg}^{-1} 40$ $\mathrm{t} \cdot \mathrm{ha}^{-1}$ CFC treated pots with a mean value of 3711 $\mathrm{mg} \cdot \mathrm{kg}^{-1}$. Phosphorus concentration in bulbs ranged from $1494 \mathrm{mg} \cdot \mathrm{kg}^{-1}$ to $3666 \mathrm{mg} \cdot \mathrm{kg}^{-1}$ with a mean value of $2640 \mathrm{mg} \cdot \mathrm{kg}^{-1}$. The highest $\mathrm{P}$ concentration of 3666 $\mathrm{mg} \cdot \mathrm{kg}^{-1}$ in bulbs was obtained by the application of $150 \%$ NPK fertilizer which showed no significant difference with CFC applied at $40 \mathrm{t} \cdot \mathrm{ha}^{-1}$. At 90 days of growth, $\mathrm{P}$ concentration in leaves ranged from $1905 \mathrm{mg} \cdot \mathrm{kg}^{-1}$ in control to $4861 \mathrm{mg} \cdot \mathrm{kg}^{-1} 40 \mathrm{t} \cdot \mathrm{ha}^{-1} \mathrm{CFC}$ treated pots with a mean value of $3145 \mathrm{mg} \cdot \mathrm{kg}^{-1}$. Phosphorus concentration in bulbs ranged from $1701 \mathrm{mg} \cdot \mathrm{kg}^{-1}$ to $5784 \mathrm{mg} \cdot \mathrm{kg}^{-1}$ with a mean value of $3429 \mathrm{mg} \cdot \mathrm{kg}^{-1}$. At both stages of growth, all the treatments significantly increased the P concentration in radish tissues compared to the control (Figure 2).

Similarly, $\mathrm{P}$ uptake (concentration $\times$ DM of plant) by the plant (plant parts) increased linearly with the rates of CFC and NPK fertilizer. Total P uptake (leaves plus bulbs) ranged from 0.26 to $5.91 \mathrm{mg} \cdot$ plant $^{-1}$ at 45 days of growth and 4.54 to $277 \mathrm{mg} \cdot$ plant $^{-1}$ at 90 days of growth. Plant P uptake was 50 times higher at 90 days of growth than at 45 days of growth, however, the trend of treatment effect was found similar at both stages of growth. Phosphorus uptake was 2 folds higher with the highest rate of CFC $\left(40 \mathrm{t} \cdot \mathrm{ha}^{-1}\right)$ than the highest rate of NPK (150\%) treatment. The results $10 \mathrm{t} \cdot \mathrm{ha}^{-1}$ of CFC was comparable with the results of $100 \%$ NPK fertilizer treatment (Figure 3).

\subsection{Available Phosphorus and pH in Soils after Plant Harvest}

The amount of available P extracted with $0.5 \mathrm{M} \mathrm{NaHCO}_{3}$ (Olsen), Mehlich-3, Kelowna and Bray \& Kurtz-1 methods ranged from 1.01 to $11.06 \mathrm{mg} \cdot \mathrm{kg}^{-1}, 4.18$ to 42.78 $\mathrm{mg} \cdot \mathrm{kg}^{-1}, 2.57$ to $25.03 \mathrm{mg} \cdot \mathrm{kg}^{-1}$ and 3.61 to $40.5 \mathrm{mg} \cdot \mathrm{kg}^{-1}$, respectively (Table 2 ). The amount of available $\mathrm{P}$ increased with the rates of treatments regardless of amendments and methods. Among the treatments, the maximum amount of available $\mathrm{P}$ extracted by four methods was observed in $40 \mathrm{t} \cdot \mathrm{ha}^{-1} \mathrm{CFC}$ treatment and the minimum in control. The amount of available $\mathrm{P}$ varied markedly, depending on the treatments and extractants used. A paired t-test was performed to compare the mean differences of $\mathrm{P}$ removed by different extractants. Tukey's multiple range test showed that the means of Olsen $\mathrm{P}$ and Kelowna P showed significant difference with Mehlich-3 and Bray and Kurtz-1 P at $\mathrm{P}<0.05$ level (Table 2) but no significant difference was observed between Olsen Kelowna P and Mehlich-3 P-Bray and Kurtz-1 P. The
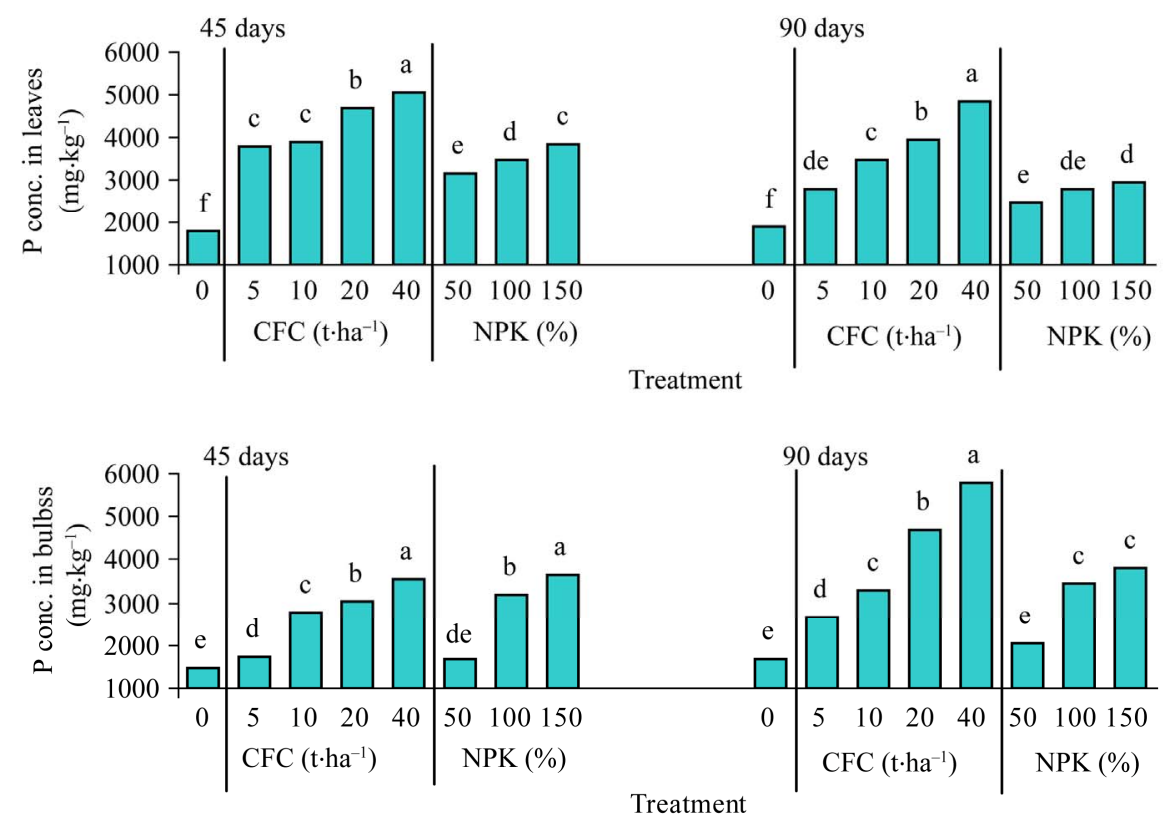

Figure 2. Effect of CFC and NPK fertilizer on phosphorus concentration in plant parts at 45 and 90 days of growth. 

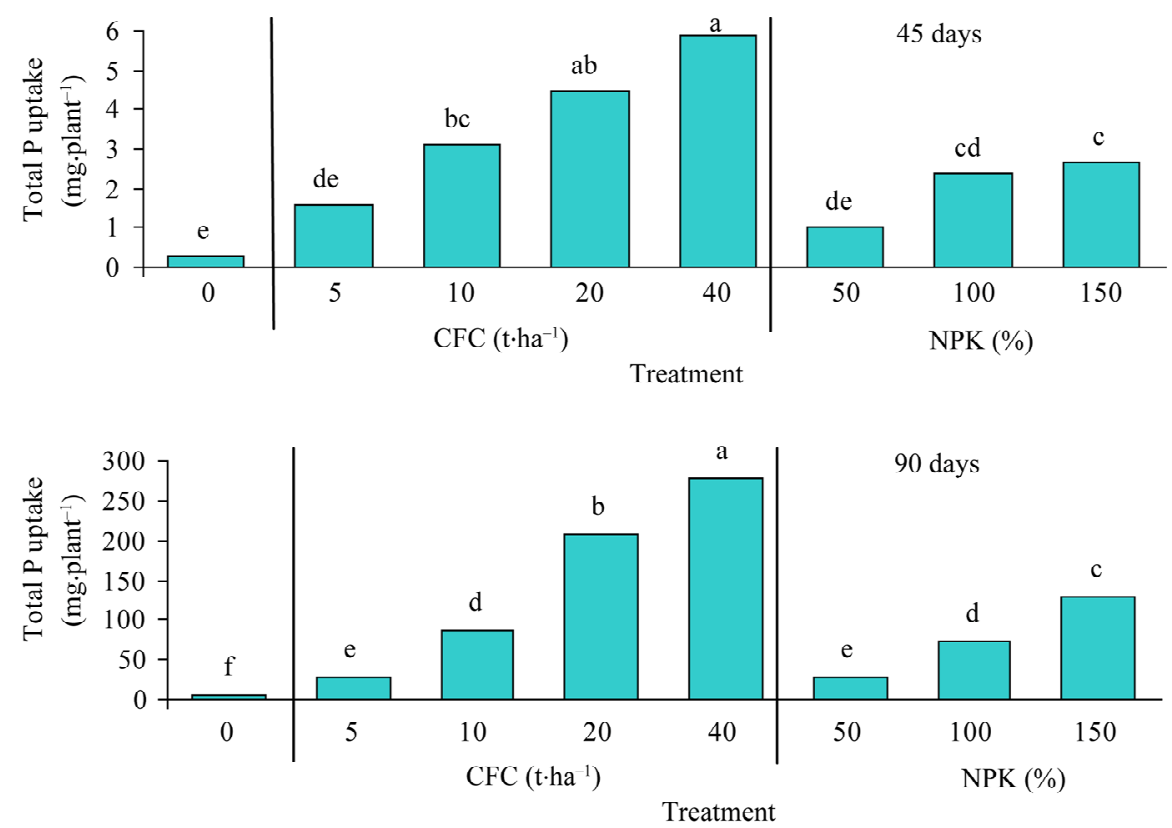

Figure 3. Effect of CFC and NPK fertilizer on total P uptake by plant at 45 and 90 days of growth.

Table 2. Effect of CFC and NPK fertilizer on extractable $P$ of soils extracted by different methods and soil pH after harvest.

\begin{tabular}{|c|c|c|c|c|c|}
\hline Treatment & Olsen P & Mehlich-3 P & Kelowna P & Bray \& Kurtz-1 P & Soil pH \\
\hline Control & $1.01 \mathrm{c}$ & $4.18 \mathrm{~g}$ & $2.57 \mathrm{~g}$ & $3.61 \mathrm{e}$ & $4.92 \mathrm{f}$ \\
\hline \multicolumn{6}{|l|}{ CFC } \\
\hline $5 \mathrm{t} \cdot \mathrm{ha}^{-1}$ & $2.24 \mathrm{c}$ & $9.53 \mathrm{e}$ & $5.38 \mathrm{ef}$ & $9.13 \mathrm{~d}$ & $5.01 \mathrm{de}$ \\
\hline $10 \mathrm{t} \cdot \mathrm{ha}^{-1}$ & $5.59 \mathrm{~b}$ & $22.50 \mathrm{c}$ & $11.23 \mathrm{c}$ & $22.87 \mathrm{c}$ & $5.14 \mathrm{c}$ \\
\hline $20 \mathrm{t} \cdot \mathrm{ha}^{-1}$ & $6.60 \mathrm{~b}$ & $28.26 \mathrm{~b}$ & $16.97 \mathrm{~b}$ & $27.55 b$ & $5.28 \mathrm{~b}$ \\
\hline $40 \mathrm{t} \cdot \mathrm{ha}^{-1}$ & $11.06 \mathrm{a}$ & 42.78 a & 25.03 a & $40.52 \mathrm{a}$ & $5.82 \mathrm{a}$ \\
\hline \multicolumn{6}{|l|}{ NPK } \\
\hline $50 \%$ & $1.99 \mathrm{c}$ & $6.42 \mathrm{f}$ & $4.03 \mathrm{fg}$ & 7.19 de & $4.94 \mathrm{ef}$ \\
\hline $100 \%$ & $2.62 \mathrm{c}$ & $9.97 \mathrm{e}$ & $6.38 \mathrm{e}$ & $10.68 \mathrm{~d}$ & $5.02 \mathrm{~d}$ \\
\hline $150 \%$ & $5.11 \mathrm{~b}$ & $23.95 \mathrm{~d}$ & $12.28 \mathrm{c}$ & $21.21 \mathrm{c}$ & $5.16 \mathrm{c}$ \\
\hline Mean & $4.53 \mathrm{~b}$ & $18.45 \mathrm{a}$ & $10.48 \mathrm{~b}$ & $17.85 \mathrm{a}$ & \\
\hline
\end{tabular}

Means followed by the same letter(s) in column(s) are not significantly different at $\mathrm{P}<0.05$.

mean values of $\mathrm{P}$ extracted by different extractants were in the order: Mehlich-3 P > Bray and Kurtz-1 P > Kelowna P > Olsen P (Table 2). Soil pH increased with the rates of CFC application but not with NPK application. The amount of soil $\mathrm{pH}$ increase was about 1 unit in $40 \mathrm{t} \cdot \mathrm{ha}^{-1}$ CFC treatments (Table 2). Soil pH showed significant positive correlations with soil $\mathrm{P}$ extracted by different extractants and DM yield.

\subsection{Correlation among Extractable P, Dry Matter Yield and $P$ Uptake by Plant}

The $\mathrm{P}$ values extracted with different methods were significantly and positively correlated $(r=0.973$ to 0.994 , P
$<0.001)$ with each other. The best correlation was found between Mehlich-3 P and Bray and Kurtz-1 P ( $\mathrm{r}=0.994)$. Level of significance was fitted to the graph as given in Figure 4. Regardless of extractants, extractable $P$ showed very strong positive correlation with DM yield and plant $\mathrm{P}$ uptake at both stages of plant growth (Figure 5), indicating that any of these extractants can be used to estimate plant available $\mathrm{P}$.

\section{Discussion}

Comparatively compost showed better plant growth than high rate of NPK fertilizer. It may be due to beneficial effects of compost in supplying plant nutrients, enhancing 

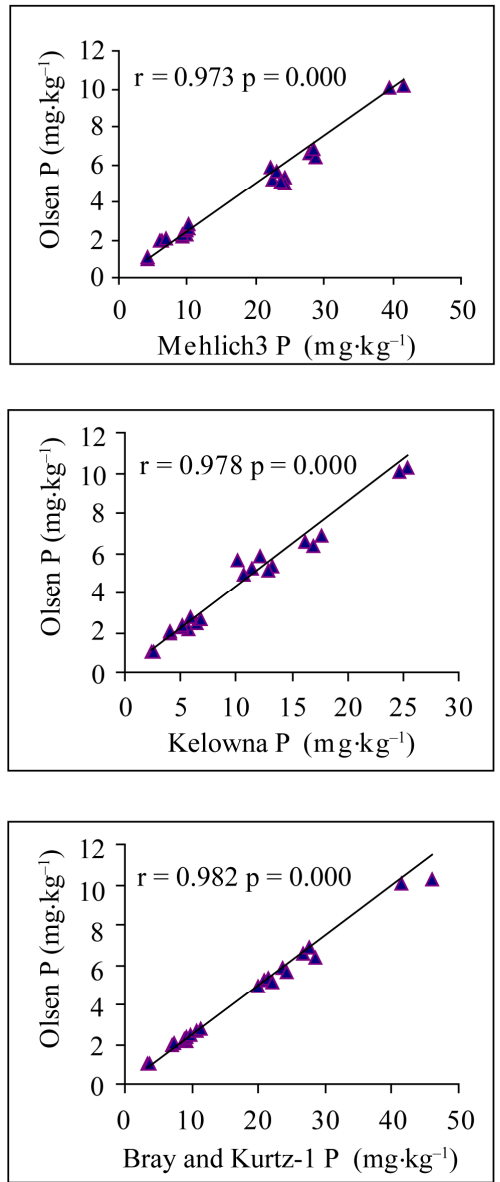
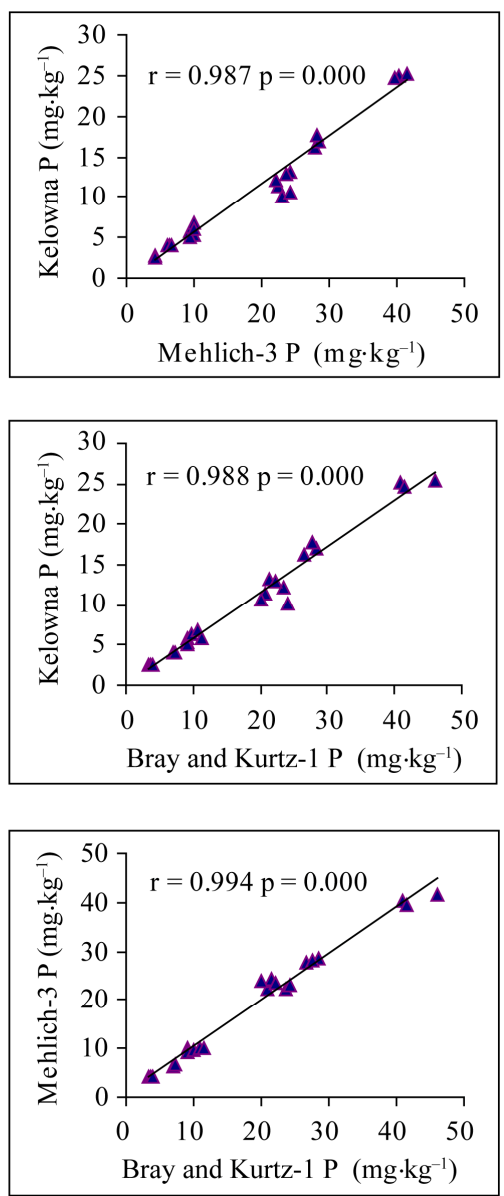

Figure 4. Correlations of available $P$ extracted by four methods.

the cation exchange capacity, improving soil aggregation, water retention and also supporting soil biological activities. The rise in productivity observed after addition of compost is attributed to the increase in the nutrient availability to the plants [19,20,35]. Metal phytotoxicity issues associated with an acid soil would also be reduced with compost addition [19].

Increased microbial activity and resulted biochemical transformations in soil, because of added organic manures may cause mineralization of more recalcitrant $\mathrm{P}$ fraction [36]. Compost reduces the $\mathrm{P}$ adsorption capacity. One possibility is that the iron, aluminum or calcium combines with humic or organic acids released by the decomposition of organic matter, thereby reducing $\mathrm{P}$ adsorption [37]. The differences among the P extractability of different methods probably arose from the fact that plant available $\mathrm{P}$ in the soil is not from a discreet fraction but from a continuum of fractions; extracting agents preferentially extract from different fractions depending on their reaction with soil components involved in $\mathrm{P}$ sorption [38]. In addition, each extracting solution has a different ability to extract varying portions of soil $\mathrm{P}$ be- cause they were targeted at different pool of soil P [39]. In the present study, Mehlich-3 extractable $\mathrm{P}$ is approximately same as that determined by the Bray and Kurtz-1 method [40]. The Bray and Kurtz-1 extractant extracts mineral phosphates of $\mathrm{Al}$ and to a lesser extent that of Fe. It is suitable for a wide range of soils, than excluding calcareous soils [41]. Fluoride forms strong complexes with aluminium $\left(\mathrm{Al}^{3+}\right)$ ions, thus releasing $\mathrm{P}$ from $\mathrm{Al}-\mathrm{P}$ [41]. Strong positive correlations among extractable $\mathrm{P}$ indicates that, although the ability of $\mathrm{P}$ extraction was different for different extractants, their trends of $\mathrm{P}$ displacement from soil into solution were similar [42].

\section{Conclusion}

Growth, plant $\mathrm{P}$ concentration, $\mathrm{P}$ uptake, soil $\mathrm{pH}$, and available $\mathrm{P}$ increased with increasing rates of CFC and NPK fertilizers. The yield response of $10 \mathrm{t} \cdot \mathrm{ha}^{-1} \mathrm{CFC}$ was similar to that of $100 \%$ NPK treatment and hence 10 $\mathrm{t} \cdot \mathrm{ha}^{-1}$ CFC would be recommended to produce optimum yield instead of $100 \%$ NPK. Strong positive correlation among available $\mathrm{P}$ extracted by different extractants and 

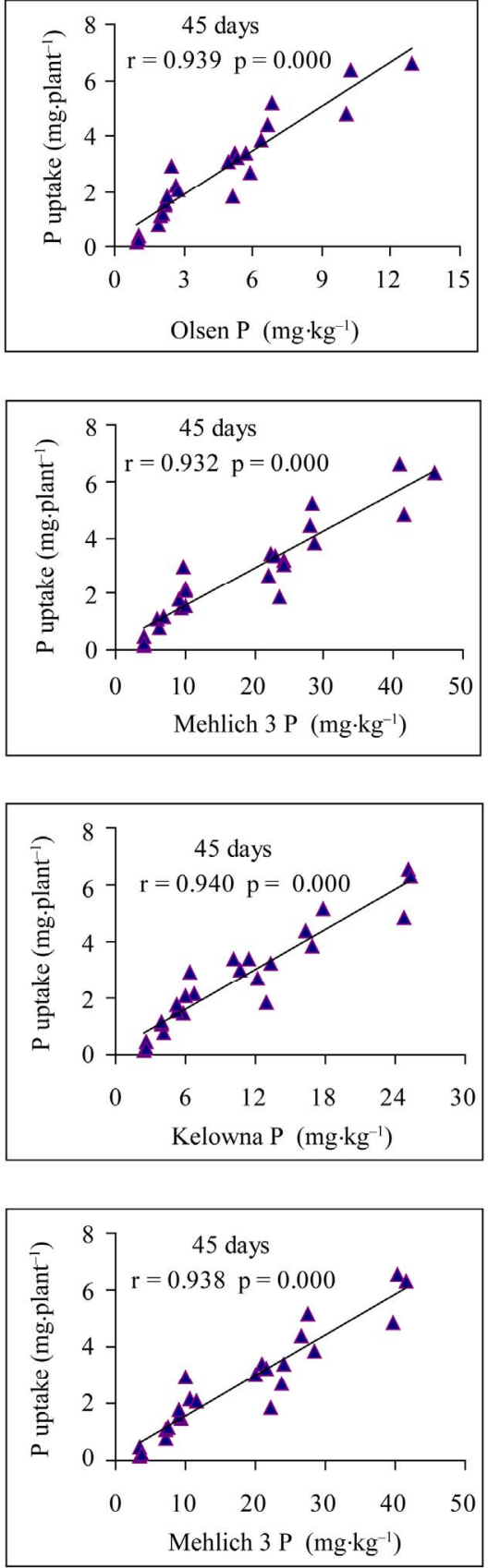
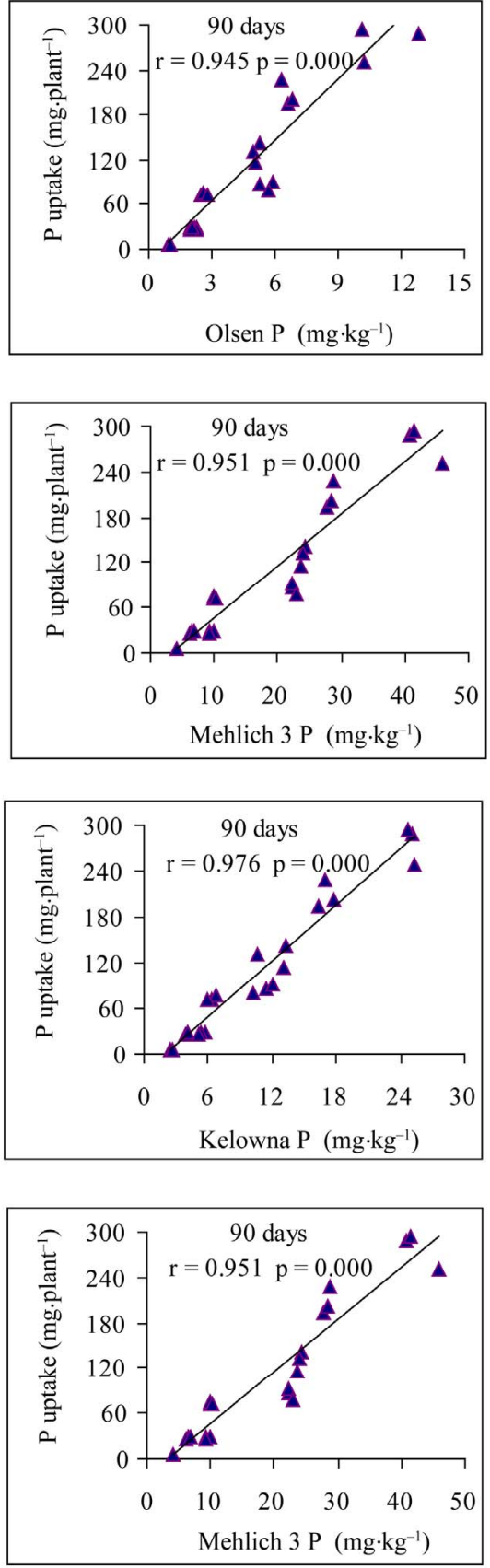

Figure 5. Correlations of available $P$ with $P$ uptake by radish at 45 and 90 days of growth.

with P uptake indicated that any of the extractants could be used to measure the status of available $\mathrm{P}$ in soil. Results of the present study, also suggest the need to investigate the effect of CFC and NPK in more detail using different soils and crops in field condition.

\section{REFERENCES}

[1] D. Cordell, J. O. Drangert and S. White, "The Story of Phosphorus: Global Food Security and Food for Thought,”
Glob Environ Change, Vol. 19, No. 2, 2009, pp. 292-305. doi:10.1016/j.gloenvcha.2008.10.009

[2] N. Gilbert, "Environment: The Disappearing Nutrient," Nature, Vol. 461, 2009, pp. 716-718. doi:10.1038/461716a

[3] M. K. C. Sridhar and G. O. Adeoye, “Organo-Mineral Fertilizer from Urban Wastes,” The Field, Vol. 68, 2003, pp. 91-111.

[4] O. T. Ayoola and O. N. Adeniyan, "Influence of Poultry on Yield and Yield Components of Crops under Different 
Cropping Systems in South West Nigeria,” African Journal of Biotechnology, Vol. 5, No. 15, 2006, pp. 13861392.

[5] J. W. C. Wong, K. K. Ma, K. M. Fang and C. Cheung, "Utilization of Manure Compost for Organic Farming in Hong Kong,” Bio-Resource Technology, Vol. 67, No. 1, 1999, pp. 43-46. doi:10.1016/S0960-8524(99)00066-8

[6] M. Naeem, J. Iqbal and M. A. A. Bakhsh, "Comparative Study of Inorganic Fertilizers and Organic Manures on Yield and Yield Components of Mungbean (Vigna radiat L.)," Journal of Agriculture \& Social Sciences, Vol. 2, No. 4, 2006, pp. 227-229.

[7] J. Bin, "Utilization of Green Manure for Raising Soil Fertility in China,” Soil Science, Vol. 135, 1983, pp. 6569. doi:10.1097/00010694-198301000-00013

[8] S. N. Dauda, F. A. Ajayi and E. Ndor, "Growth and Yield of Water Melon (Citrullus lanatus) as Affected by Poultry Manure Application,” Journal of Agriculture \& Social Sciences, Vol. 4, 2008, pp. 121-124.

[9] K. D. Suresh, G. Sneh, K. K. Krishn and C. M. Mool, "Microbial Biomass Carbon and Microbial Activities of Soils Receiving Chemical Fertilizers and Organic Amendments," Archives of Agronomy and Soil Science, Vol. 50, No. 6, 2004, pp. 641-647. doi:10.1080/08927010400011294

[10] M. Usman, E. Ullah, E. A. Warriach, M. Farooq and A. Liaqat, "Effect of Organic and Inorganic Manures on Growth and Yield of Rice Variety Basmati 2000," International Journal of Agriculture and Biology, Vol. 5, 2003, pp. 481-483.

[11] I. Khaliq, N. Parveen and M. A. Chowdhry, "Correlation and Path Coefficient Analyses in Bread Wheat," International Journal of Agriculture and Biology, Vol. 6, No. 4, 2004, pp. 633-635.

[12] D. Muhammad and R. A. Khattak, "Growth and Nutrient Concentration of Maize in Pressmud Treated Saline-Sodic Soils," Soil Environment, Vol. 28, No. 2, 2009, pp. 145155.

[13] F. Mujeeb, M. A. Rahmatullah, A. Hannan and M. A. Maqsood, "Response of Maize to Di-Ammonium Phosphate and Farmyard Manure Application on Three Different Soils,” Pakistan Journal of Agricultural Science, Vol. 45, 2008, pp. 13-18.

[14] S. K. Singh, M. C. Prasad, S. Nem and C. Ramakrishna, "Clino-Biochemical Studies on Induced Pregnancy Toxaemia in Sheep," Indian Journal of Veterinary Pathology, Vol. 16, No. 2, 1992, pp. 85-90.

[15] P. Mantovi, G. Baldoni and G. Toderi, "Reuse of Liquid, Dewatered, and Composted Sewage Sludge on Agricultural Land: Effects of Long-Term Application on Soil and Crop,” Water Research, Vol. 39, No. 2-3, 2005, pp. 289296.

[16] M. P. de Smet Inckel, T. Tersmette and T. Veldkamp, "The Preparation and Use of Compost," Fourth Edition, Wagenningen, the Netherlands, 1996, p. 28.

[17] M. P. Bernal, F. A. Navarro, A. M. Sánchez-Monedero, A. Roig and J. Cegarra, "Influence of Sewage Sludge Com- post Stability and Maturity on Carbon and Nitrogen Mineralization in Soil," Soil Biology and Biochemistry, Vol. 30, No. 3, 1998, pp. 305-313. doi:10.1016/S0038-0717(97)00129-6

[18] J. Casado-Vela, S. Selles, C. Díaz-Crespo, J. NavarroPedreño, J. Mataix-Beneyto and I. Gómez, "Effect of Composted Sewage Sludge Application to Soil on Sweet Pepper Crop (Capsicum annuum var. annuum) Grown under Two Explotation Regimes," Waste Manage, Vol. 27, No. 11, 2007, pp. 1509-1518. doi:10.1016/j.wasman.2006.07.016

[19] M. A. Kashem and B. R. Singh, "Solid phase speciation of $\mathrm{Cd}, \mathrm{Ni}$ and $\mathrm{Zn}$ in Some Contaminated and Non-Contaminated Tropical Soils,” In: I. K. Iskandar and M. B. Krikham, Eds., Trace Elements in Soil, Bioavailability, Flux and Transfer, Lewis Publishers, CRS Press, Boca Raton, 2001, pp. 213-227. doi:10.1201/9781420032734.ch11

[20] V. D. Zheljazkov and P. R. Warman, "Application of High Cu Compost to Swiss Chard and Basil,” Science of Total Environment, Vol. 302, No. 1-3, 2003, pp. 13-26. doi:10.1016/S0048-9697(02)00390-X

[21] J. L. McCoy, L. J. Sikora and R. R. Weil, "Plant Availability of Phosphorus in Sewage Sludge Compost," Journal of Environmental Quality, Vol. 15, No. 4, 1986, pp. 403-409. doi:10.2134/jeq1986.00472425001500040016x

[22] P. M. Gale, M. D. Mullen, C. Cieslik, D .D. Tyle, B. N. Duck, M. Kirchner and J. McClure, "Phosphorus Distribution and Availability in Response to Dairy Manure Applications," Communications in Soil Science and Plant Analysis, Vol. 31, No. 5-6, 2000, pp. 553-565. doi:10.1080/00103620009370459

[23] M. A. Kashem, O. O. Akinremi and G. J. Rez, "Phosphorus Fraction in Soil Amended with Organic and Inorganic P Sources,” Canadian Journal of Soil Science, Vol. 84, No. 1, 2004, pp. 83-90. doi:10.4141/S03-018

[24] M. A. Kashem, O. O. Akinremi and G. J. Rez, "Extractable Phosphorus in Alkaline Soils Amended with High Rates of Organic Amendments," Canadian Journal of Soil Science, Vol. 84, No. 4, 2004, pp. 459-467. doi:10.4141/S03-085

[25] A. Walkley and I. A. Black, “An Examination of Degtjareff Method for Determining Soil Organic Matter and a Proposed Modification of the Chromic Acid Titration Method," Soil Science, Vol. 37, No. 1, 1934, pp. 29-38. doi:10.1097/00010694-193401000-00003

[26] Soil Survey Laboratory Staff, "Soil Survey Laboratory Methods Manual,” Soil Survey Investigation Report, 42, USDA-SCS, Washington DC, 1992.

[27] G. J. Bouyoucos, "Hydrometer Method Improved for Making Particle Size Analysis of Soils,” Agronomy Journal, Vol. 54, No. 5, 1962, pp. 464-465. doi:10.2134/agronj1962.00021962005400050028x

[28] S. R. Olsen, C. V. Cole, F. S. Watanabe and Dean, "Estimation of Available Phosphorus in Soils by Extraction with Sodium Bicarbonate,” USDA Circular No. 939, U.S. Government Printing Office, Washington DC, 1954.

[29] A. Mehlich, "Mehlich 3 Soil Test Extractants: A Modifi- 
cation of Mehlich 2 Extractant," Communications in Soil Science and Plant Analysis, Vol. 15, No. 12, 1984, pp. 1409-1415. doi:10.1080/00103628409367568

[30] W. Ven Lierop, "Determination of Available Phosphorus in Acid and Calcareous Soils with Kelowna MultipleElement Extractant," Soil Science, Vol. 146, 1988, pp. 284-291. doi:10.1097/00010694-198810000-00009

[31] R. H. Bray and L. T. Kurtz, "Determination of Total Organic and Available Forms of Phosphorus in Soils," Soil Science, Vol. 59, No. 1, 1945, pp. 39-45. doi:10.1097/00010694-194501000-00006

[32] J. Murphy and J. P. Riley, “A Modified Single Solution Methods for the Determination of Available Phosphate in Natural Water," Analytica Chimica Acta, Vol. 27, 1962, pp. 31-36. doi:10.1016/S0003-2670(00)88444-5

[33] O. O. Akinremi, N. Amisen, M. A. Kashem and H. H. Janzen, "Evaluation of Analytical Methods for Total P in Organic Amendments," Communications in Soil Science and Plant Analysis, Vol. 34, No. 19-20, 2003, pp. 29812991. doi:10.1081/CSS-120025220

[34] Minitab Inc., “Minitab User Guide Release 11,” Minitab, State College, 1996.

[35] M. A. Kashem and P. R. Warman, "Effect of Application of Chromium Feedstock Compost on the Growth and Bioavailability of Some Trace Elements in Lettuce," Communications in Soil Science and Plant Analysis, Vol. 40, No. 15-16, 2009, pp. 2426-2439. doi:10.1080/00103620903111327

[36] G. Nziguheba, C. A. Palm, R. J. Buresh and P. C. Smithson, "Soil Phosphorus Fractions and Adsorption as Affected by Organic and Inorganic Sources,” Plant and Soil,
Vol. 198, No. 2, 1998, pp. 159-168. doi:10.1023/A:1004389704235

[37] N. J. Barrow, “Testing a Mechanistic Model. IX. Comparison between Anions for Sorption by Soil," Journal of Soil Science, Vol. 40, 1989, pp. 415-425. doi:10.1111/j.1365-2389.1989.tb01284.x

[38] CAST, "Relevance of Soil Testing to Agriculture and the Environment," Council for Agricultural Science and Technology, Issue Paper Number 15, 2000.

[39] M. Zhang, R. Wright, D. Heaney and D. Vanderwel, "Comparison of Different Phosphorus Extraction and Determination Methods Using Manure Soils,” Canadian Journal of Soil Science, Vol. 84, No. 4, 2004, pp. 469-475. doi:10.4141/S02-023

[40] D. D. Tran, A. B. Groeneveld, J. V. Meulen, J. J. Nauta, R. J. S. Schijndel and L. G. Thijs, “Age, Chronic Disease, Sepsis, Organ System Failure and Mortality in a Medical Intensive Care Unit," Critical Care Medicine, Vol. 18, No. 5, 1990, pp. 474-479. doi:10.1097/00003246-199005000-00002

[41] E. J. Kamprath and M. E. Watson, "Conventional Soil and Tissue Tests for Assessing the Phosphorus Status of Soils,” In: F. E. Khasawneh, et al., Eds., The Role of Phosphorus in Agriculture, ASA, CSSA, and SSSA, Madison, 1980.

[42] G. K. M. M. Rahman, M. Jahiruddin, M. I. Ali, M. S. Hoque and M. Q. Haque, "Effect of Soil Properties on the Extraction of Phosphorus and Its Critical Limit for Rice," Indian Society of Soil Science, Vol. 43, No. 1, 1995, pp. 67-71. 